\title{
The New Teaching Mode of College English in China Based on Multimedia and Network Technology
}

\author{
Huang Tian E \\ Foreign Language Teaching Department \\ Hebei University of Economics and Business \\ Shijiazhuang City, Hebei 050061, China \\ Email: hte0588@163.com
}

\begin{abstract}
This paper makes an exploration on the new mode of college English language teaching in China based on multimedia and network technology. In particular, it focuses on explaining the advantages of the new teaching mode of college English by taking an example of experimenting in the researcher's university, and points out the necessity to make full use of multimedia and network technology in college English teaching, which can give full scope to student-centered and teacher-guided teaching method, promote students' autonomous learning and arouse their interests in learning English so as to improve college English teaching quality.
\end{abstract}

Keywords -the new teaching mode, multimedia and network technology, Blackboard Learning System, English Language Learning Center, autonomous learning

\section{INTRODUCTION}

In 2007, China Ministry of Education issued College English Curriculum Requirements, which relates: “...... colleges and universities should make full use of modern information technology to remodel the existing unitary teacher-centered pattern of language teaching. The new teaching mode should be built on modern information technology, particularly network technology so that English language teaching will be free from the constraints of time or place and geared towards students' individualized and autonomous learning." [1] The college English teaching reform has been going with the College English Curriculum Requirements. The teacher-centered traditional college English teaching mode is far from satisfaction of modern English teaching development, therefore, it's necessary to reform the traditional college English teaching mode and adopts the new teaching one, just as the new requirements does----asking for an integration of multimedia and network technology into college English language teaching and learning. Apparently, computers and network are essential elements in education, and the field of college English language teaching appeals to colleges and universities to adopt new mode in order to improve teaching quality, i.e. the new mode of college English language teaching based on multimedia and network technology.

\section{THEORETICAL BASES}

The new mode of college English teaching is based on the integration of applied pedagogy, psychology and linguistics.
Firstly, the new mode of college English teaching is based on constructive learning which Piaget made much contribution to. Constructivism theory emphasizes learnercenteredness, collaborative learning, autonomous learning and authentic learning environment. It stresses the positive meaning construction of the learners [2]. The new mode of college English teaching based on multimedia and network technology is just the refection of such new teaching method.

Secondly, the new mode of college English teaching is also based on Krashen's theory of input hypothesis concerning second language learning [3]. The ideal input is interesting and relevant, and only when there is enough input, can the learners learn second language unconsciously. The new college English teaching mode based on multimedia and network technology can make the students in an ideal input situation.

Thirdly, American psychologist Bruner holds that the best motivation of learning is to get interested in what one learns [4]. The new teaching mode takes advantage of multimedia and network technology to create vivid and authentic learning environment for students so that they become interested in what they are learning and eager to communicate in English in such real, natural and vivid language environment.

And the famous linguist and educator David Nunan emphasizes to set up subject and classroom teaching based on students-centeredness. He stresses that what, when and how is taught should be student-centered [5]. The new mode of college English teaching based on multimedia network technology is right to satisfy such teaching requirements.

\section{THE STRUCTURE AND CHARACTERISTICS OF THE NEW TEACHING MODE}

\section{A. The Traditional Teaching Mode}

The traditional English language teaching and learning in China which is dominated by the teacher-centered method, or the book-centered and grammar-centered method and an emphasis on rote memory has long proved gone out of date. As we know, it cannot use multi-media, computer network technology and some other information resources to conduct teaching. Many teachers just rely on the textbooks and coach books, which has little information and cannot help the students to construct their knowledge actively. Teachers mainly taught students vocabularies and grammar rules in the classroom teaching, overlooking to develop students' 
abilities to use English language. Furthermore, in traditional English teaching classroom, instructions are given according to how the teacher views teaching and learning, neglecting the students' initiative and contribution. More often than not, forced feeding is practiced while the learner's interest and motivation fall miserably to the bottom. Therefore, a more modernized and more effective educational system, asking for the change of the situation in which the teacher acts as a knowledge dispenser while students are only passive recipients, is badly needed.

\section{B. Multimedia and Network Technology in the New Teaching Mode}

The multimedia and network technology has been developing rapidly in the past few years. Network resources should take an important role in college English teaching, of which the students-centered pattern should be promoted so that students' potential of autonomous learning can be developed. Multimedia computers can provide an accurate portrayal of the target language and provide learners with control and feedback. More importantly, they facilitate a methodological and theoretical advance emphasizing input and intake. Multimedia also provides a massive storehouse of records to facilitate authentic learning [6]. Besides, multimedia provides support for different learning styles of language learners by deploying different neuron-systems in learning through its reliance on sound, color, and animation [7].

Though the classroom remains an important environment for students, it is not in itself a thoroughly authentic learning context. The Internet, however, provides the possibility of creating a virtual reality for students. The vivid images of virtual classroom could fuel students' motivation to learn English [8].

So the new college English teaching mode based on multimedia and network technology provides students ample opportunity to practice their English listening, speaking, writing and reading comprehension. In addition to face-toface interaction with one another, students may speak English in a virtual reality setting using the software of English Autonomous Learning Center, as well as chatting online with other communities of English learners in China and abroad. The authenticity of the learning environment provides students with the chance to study English through doing rather than learning [9].

\section{Experimental Presentation and Analysis}

Since 2006, we have adopted the new teaching mode of college English based on multimedia and network technology in 16 teaching classes in our university. After the solid 4 years practice, we have formed the steady teaching mode. As to the teaching method, attention should be paid to the balanced development of language skills, providing authentic learning environments, fostering autonomous learning, as well as establishing a student-centered, teacherguided approach. The concrete process is:

3-period intensive reading a week in the multimedia classroom in which the teacher makes better use of multimedia technology to create the authentic language environment with pictures, movies and sounds so that students interact easily with classmates and the teacher.

2-period listening and speaking classes a week in the language lab, in which students can surf on campus net guided and supervised by teachers, and students can listen, look and learn in the teaching steps such as lead-in, listening skills, speaking out, let's talk and further listening.

And students can also learn English online after class in their spare time either on the campus net of English Language Autonomous Learning Center (see Figure 1) or on Blackboard Learning System (see Figure 2) according to their time and their interests. Teachers supply rich online learning resources.

Anyway, multimedia and network technology plays an important part in the new teaching mode of college English. The teacher interacts with students by guiding, supervising and managing on the Internet. The process can be shown in Figure 3 (see Figure 3).

The new teaching mode has the following advantages:

a) The new teaching mode of college English based on multimedia and network technology has remodeled the traditional teaching mode of "textbook + blackboard + chalk". The new mode is informative, student-centered, and all classroom activities are focusing on students so that the students are in the best English language learning environment. As a result, students can learn English in a very relaxed and effect way by using all their senses. During the teaching experiment, the researcher found that the students in the pilot classes were no longer passive, silent, isolated learners, but active participants and autonomous learners. Furthermore, in the process of teaching, the teacher provides the students with a variety of realistic autonomous learning approaches, which is feasible in a real learning process, and teachers also develop students' autonomous learning interest in knowledge self-construction process by giving students opportunities to think individually and independently.

b) The new teaching mode emphasizes the learning is resources-based learning, which requires the students to learn automatically and cooperatively with the help of various resources. The new mode makes full use of modern information technology and sharing resource to construct ideal learning environment, which can not only stimulate students' interest and activeness in learning English but also arouse the enthusiasm of the students to learn English and enhance their thinking patterns in English, especially facilitate students' autonomous learning. The most successful aspect of the new teaching mode is that students' interest in English learning got motivated and students became more independent. Through learning English on campus net of English Language Autonomous Learning Center, students become more and more independent in learning English and completing their learning tasks. What's more, they could notice each of progress by it and greatly enhanced their confidence in English learning. They know how to make use of the network and how to get cooperated with classmates in learning.

c) The use of computers in the new teaching mode brings out rich teaching resources for teachers so that they can choose whatever they like to show students. For example, 
teachers can choose variety of materials such as movies, TV programs, songs, short news broadcasting and so on except for CD attached to textbooks. Usually, the teacher posts the above materials on Blackboard Learning System. Therefore, students use these teaching materials to practice listening and imitate the native speakers. Meanwhile the students can learn English online at anytime they like to and they can feel authentic language materials by network technology. Teachers can guide the students to actively and consciously construct a plan of study that goes beyond their timetable of classes, reflect their learning and bring forward their own questions and so on. In the whole teaching process, students are supplied with a dynamic teaching environment and they are widened horizon, richened imagination and stimulated interests so that the classroom teaching effects are improved by the efficient learning and practicing.

d) The new teaching mode brings the learners' initiative into full play by letting them do interesting and meaningful tasks that are close to real life events. Carefully designed and well-graded, the tasks not only give the learners a chance to use the language in real communication, but also enhance their ability for creative thinking and problem-solving. They become real participants while the instructor is reduced to the status of a designer, organizer, counselor, and facilitator. This approach, seemingly shifting the burden onto learners, is in fact more demanding for the teacher, as the designing of good tasks and on-the-spot organization calls for more alertness and resourcefulness [10].

In the researcher's university, 16 classes (in Grade 2006, Grade 2007, and Grade 2008) are chosen at random to be pilot classes which adopt the new teaching mode by using multimedia and network technology (note: we cannot use the new mode in all classes because of limited teaching equipments and teaching materials). After 4 years' teaching practice, the effect is quite good, and the teaching achievements are improved year by year. Take the rate of students' passing CET4 ( short for College English Test Band 4) in Grade 2008 for example, as in Figure 3, the rate of passing CET4 is $87.61 \%$ while the rate in pilot classes is 93.69\%. Apparently, the teaching results in pilot classes are much better just as shown in Figure 4 (see Figure 4).

\section{SUGGESTIONS AND IMPLICATIONS}

The essence of college English teaching reform is to satisfy the requirements of the times - cultivate students' practical ability of using English. The application of computers in English teaching has certain advantages, but it can not replace teachers' guidance and explanation. In effect, this teaching mode has higher requirements to teachers' English knowledge and teaching management. So the following should be paid more attention to in the process of teaching:

a) Teachers should know how to use the equipments of multimedia classroom, language lab and network, which can guarantee facilitating the teaching process. So should students improve their computer literacy.

b) Just as we know, the modern information technology, especially the technology of multimedia and computer networks, has provided the students with a lot of learning resources. The teachers should set up authentic language situation and provide intuitive, visual and interactive learning environment for the students to learn cooperatively. Therefore, what the teacher should do is not giving all the resources directly to the students but guiding them to search for and make use of the resources by themselves. And more importantly, teachers should choose materials carefully for students. The materials should have a close relationship with the students' daily life and with the content of the text, which should be neither too difficult nor too easy for fear that the students should lose learning interest and motivation. Proper materials can result in high motivation and interest in learning and in turn benefits students' achievement. And what materials teachers choose should give students opportunities to express themselves personally about their interest, goals, and desires using English by learning online without the pressure that students may feel during the classroom learning.

c) Teachers should help students set up learning goals, make autonomous learning plan, and give students more time and space to do autonomous learning. And teachers should recommend learning strategies according to different learning tasks and cultivate students' abilities of autonomous learning, trying to give full scope to students' initiatives and use such teaching methods as are best adapted to the students. Furthermore, teachers should gradually develop students' psychological emotional learning ability, and encourage students to cooperate with classmates in discussion, interaction and evaluation. Whenever students encounter problems in learning, help from their teachers and peers is available on the net. However, collaborative learning does not refer to the help from others only. It also includes communicative tasks which require joint efforts from every participant, both teachers and students. By doing such exercises, several advantages would be gained. Students are stimulated to communicate and as a result, their communicative competence will be improved. What's more, their intellectual resources and creativity will be developed to some extent; and their friendship will be promoted. It is rather obvious that both independent learning and collaborative learning contribute to the improvement of students’ English.

\section{CONCLUSION}

Just as the preceding discussion, the application of multimedia and computer network technology in college English language teaching is not only the shift of teaching activities or teaching methods but also the shift of teaching ideas. It is a kind of shift from teacher-centered teaching mode which emphasizes language knowledge and skills to student-centered teaching mode which pays more attention to developing language applied ability and autonomous learning. The study shows that the new teaching mode of college English based on multimedia and network technology is a positive one, which can improve students applied ability of English language. It can bring the students plenty of resources vividly to arouse much interest among the students, and it can create an authentic teaching 
environment for them to improve their English. It is hoped that the study can provide an efficient way for the teachers to use in English teaching and improve the English teaching quality.

However, no teaching mode is perfect. During the study, the researcher has discovered that some factors interfere with teachers and students in the use of multimedia and network technology, particularly first, teachers and students' computer literacy which plays a vital role in teaching process, and second, the slow speed of campus net may influence the teaching and learning efficiency. Therefore, it would be very insightful to study how both teachers and students improve their computer literacy and to what extent campus net is speeded.

Notes: this paper is the project achievement in scientific research of Hebei University of Economics \& Business with the title "Exploration on Blended Teaching Mode of College English Based on Blackboard Learning System", and the project number is 2012JYZ02.

\section{REFERENCES}

[1] Higher Education Department of Education Ministry, "College English Curriculum Requirements,” Higher Education Press, p. 6 2007.

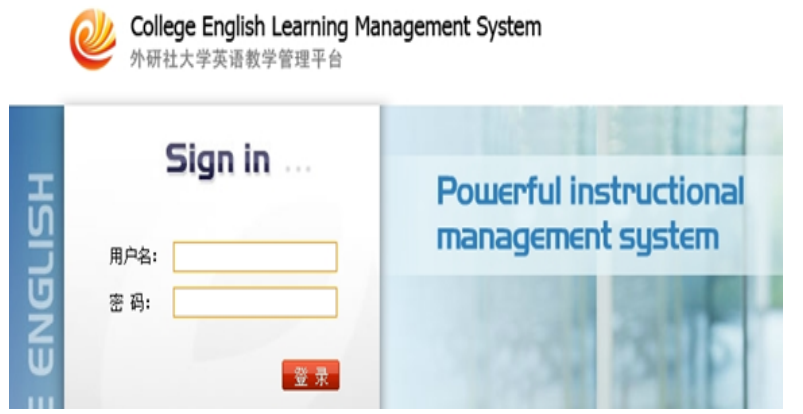

Figure 1: interface of logging in English Language Autonomous Learning Center

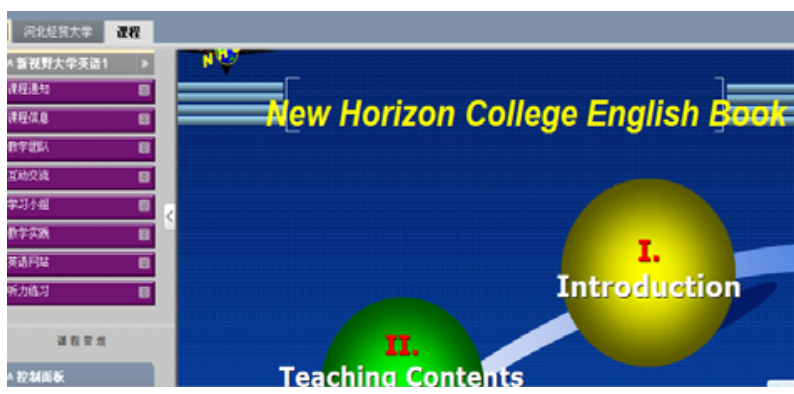

Figure 2: interface of Blackboard Learning System
[2] J. Piaget, Structuralism. New York: Basic Books, 1970

[3] Krashen, S, Second Language Acquisition and second Language Learning . Oxford: Pergamon, 1981.

[4] J. S. Bruner, The Process of Education. Cambridge, Mass: Harvard University Press, 1960

[5] D. Nunan, "Second language teaching and learning", .Beijing: Foreign Language Teaching and Research Press, 2001:11.

[6] J. P. Pusack and S. K. Otto, “Applying Instructional Technologies”, Foreign Lanuage Annals, vol 23,pp. 409-417,1990.

[7] E. Hanson-Smith, "Technology in the Classroom: Practice and Promise in the $21^{\text {st }}$ Century," URL: http://www.tesol.edu/pubs/profpapers/techclass. html

[8] Zhu Xiaoshen, "Incorporating Computer Multimedia and Web into English Learning: an Integrated Course Design for Chinese Undergraduates ”, CELEA Journal, Vol. 27, 2004, pp. 77.

[9] R. LeBlanc, National Core French Study: A Synthesis, Ottawa: Canadian Association of Second Language Teachers.

[10] Liu Runqing and Dai Manchun, "On the Reform of College English in China,” CELEA Journal, vol. 27, 2004, pp. 5-6.

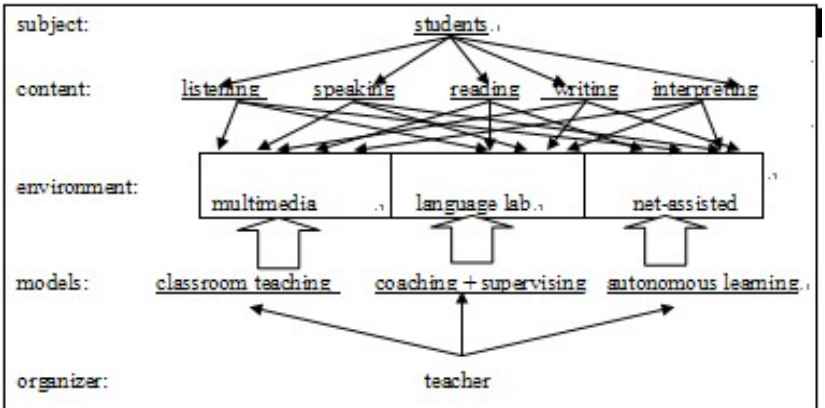

Figure 3: the new mode of college English teaching based on multimedia \& network technology

(A part of the diagram is from College English Curriculum Requirements)

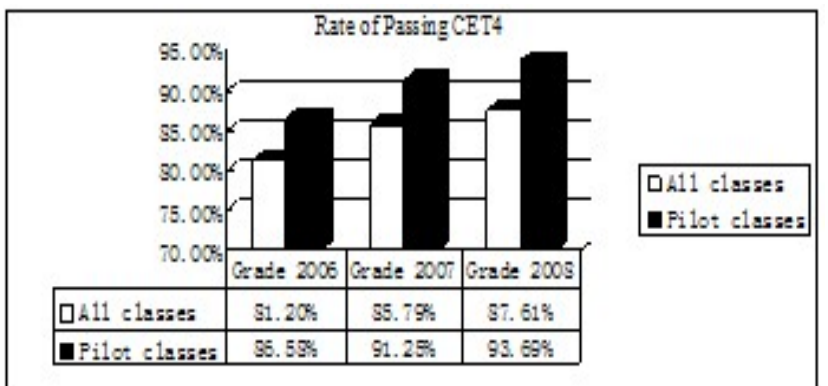

Figure 4: Rate of passing CET4 